УДК 811.111'271:305:324

DOI https://doi.org/10.26661/2414-1135-2021-82-9

\title{
ENGXIT ЧИ EURO-ENGLISH: НОВI РЕАЛІЇ АНГЛІЙСЬКОЇ МОВИ В ЄС
}

\author{
Данильчук А. Л. \\ кандидат філологічних наук, доцент, \\ дочент кафедри прикладної лінгвістики \\ Волинський національний університет імені Лесі Украӥнки \\ пр. Волі, 13, Луиььк, Украӥна \\ orcid.org/0000-0001-8127-2953 \\ danylchuk@vnu.edu.ua
}

Ключові слова: lingua franca, мультилінгвізм, мовна політика, варіанти англійської мови, офіційна мова, робоча мова.
Вихід Великобританії з Свропейського Союзу, відомий як брекзит, привернув увагу політиків і дослідників до майбутнього англійської мови в ЄС. Попри анонсовану політику мультилінгвізму, головними робочими мовами Свропейського Союзу впродовж останніх десятиліть були англійська, французька та німецька мови з великим домінуванням англійської як мови міжкультурної комунікації. Серед імовірних прогнозів функціонування англійської мови в СС після брекзиту спостерігаються дві радикально протилежні точки зору - від повного припинення іiі використання у сфері офіційної комунікації Європейського Союзу до утвердження нового європейського варіанта, відмінного від стандартної англійської мови. У статті на матеріалі аналізу англомовного медійного дискурсу СС 2016-2021рр. запропоновано визначення терміна ENGXIT; здійснено огляд медійних і наукових публікацій щодо функціонування англійської мови в Свропейському Союзі до тапісля виходу Великобританії 3 його складу. Спираючись як на результати аналізу емпіричного матеріалу дослідження, так i на офіційні заяви відповідальних за мовну політику СС управлінців і науковців, бачимо, що в найближчому майбутньому англійська мова залишатиметься однією 324 офіційних мов і трьох активних робочих мов Свроспільноти. Зважаючи на те що в проаналізованих публікаціях англомовних медійних видань ЄС після 2016 року рідко вживається термін ENGXIT, натомість особливо часто зустрічаються висловлювання щодо європейського варіанта англійської мови, так званого Euro-English, припускаємо, що вихід Великобританії 3 Свропейського Союзу може слугувати поштовхом до кодифікації нового варіанта англійської мови та його подальшого активного використання в офіційній комунікації Свропейського Союзу. Результати дослідження демонструють унікальну, об'єднавчу роль англійської мови в сучасному глобалізованому суспільстві ЄС і неготовність громадян Євроспільноти відмовлятися від іï вжитку в найрізноманітніших сферах життя - від освіти й культури до політики та економіки. 


\title{
ENGXIT OR EURO-ENGLISH: NEW REALITIES OF THE ENGLISH LANGUAGE IN EU
}

\author{
Danylchuk A. L. \\ Candidate of Philological Sciences, Associate Professor, \\ Associate Professor at the Department of Applied Linguistics \\ Lesya Ukrainka Volyn National University \\ Voli avenue, 13, Lutsk, Ukraine \\ orcid.org/0000-0001-8127-2953 \\ danylchuk@vnu.edu.ua
}

Key words: lingua franca, multilingualism, language policy, English language variants, official language, working language.

\begin{abstract}
Britain's exit from the European Union, known as Brexit, has drawn much attention to the future of English in the EU. Despite the announced policy of multilingualism, the main working languages of the European Union in recent decades have been English, French and German, with a strong predominance of English as the language of intercultural communication. Among the predictions on the future of English in the EU after Brexit, there are two radically opposite views - from the complete cessation of its use in the official communication of the European Union, to the adoption of a new, European version other than standard English. The article, based on the analysis of the English-language media discourse of the EU 2016-2021, proposes the definition of the term ENGXIT; a review of media and scientific publications on the functioning of the English language in the European Union before and after Brexit is made. The results of the empirical material analysis, as well as the official statements of politicians and scholars responsible for the EU language policy, demonstrate that in the near future English will remain one of the 24 official languages and three active working languages of the European Community. Given that the term ENGXIT is rarely used in the analyzed EU English-language media publications after 2016, and the European version of the English language, the so-called Euro-English, is particularly common, we suggest that Brexit may trigger codification of a new version of the English language with its further active use in the official communication of the European Union. The results of the study also demonstrate the unique, unifying role of the English language in today's globalized EU society and the unwillingness of EU citizens to abandon its use in a wide range of life situations, starting from education and culture to politics and economics.
\end{abstract}

Постановка проблеми. Вихід Великобританії з Європейського Союзу є однією з найважливіших геополітичних подій XXI століття, що супроводжується великою увагою суспільства. Ставлення до брекзиту $є$ неоднозначним по обидва боки Ла-Маншу, проте беззаперечним залишається факт: таке переформатування має потенціал змінити не лише життя країн-членів $\mathrm{CC}$, а й усього світу. 3 червня 2016 року, коли 52\% британців проголосували за вихід із Свропейського Союзу, i до грудня 2020 року, коли країна після низки внутрішніх і зовнішніх політичних конфліктів усе ж остаточно вийшла з $€ \mathrm{C}$, у фокусі суспільної уваги була низка економічних, соціальних, культурних і лінгвістичних питань.

У грудні 2016 року рекордно швидко як для стандартів лексикографії термін BREXIT, утворений складанням прикметника British та іменника exit, увійшов до онлайн версії Oxford English Dictionary. Як зазначалося в статті служби ВВС 2016 року, словник визначає "Brexit as "the (proposed) withdrawal of the United Kingdom from the European Union, and the political process associated with it. Sometimes used specifically with reference to the referendum held in the UK on 23rd June 2016, in which a majority of voters favoured withdrawal from the EU" [1]. Сьогодні знаходимо в цьому ж словнику вже інше визначення терміна, адаптоване до нових реалій: “... used to refer to the departure of the United Kingdom from the European Union" [2]. Майже одночасно з терміном BREXIT за аналогією $з$ ним утворено інший, менш популярний, проте все ж уживаний в англомовній пресі термін ENGXIT. Наприклад, кілька заголовків англомовних онлайн медіа: "Brexit should not mean Engxit too" [3], "Johnson Promised Brexit-But May Deliver Engxit” [4]. 
Мета й завдання статті. Термін ENGXIT до словників не потрапив, проте, зважаючи на частотність його використання в англомовній пресі 2018-2021 рр., зацікавив нас своїми потенційними значеннями. Оскільки одним із популярних контекстів його використання були публікації щодо майбутнього англійської мови в ЄС (після виходу 3 нього Великобританії), ми поставили перед собою низку завдань: запропонувати своє визначення ENGXIT, спираючись на проаналізований емпіричний матеріал, і спрогнозувати ймовірні сценарії використання англійської мови в Європейському Союзі після 2021 року. Тож, у широкому розумінні, об'єктом дослідження $\epsilon$ сучасний варіант англійської мови, що використовується в Європейському Союзі, а предметом дослідження - функціонування англійської мови в контексті виходу Великобританії з СС і потенційний феномен так званого ENGXIT.

Виклад основного матеріалу дослідження. Як ми вже зазначали, термін ENGXIT до словників не потрапив. Проте, аналізуючи культурний і лінгвістичний контекст, у якому цей термін уживається, бачимо мінімум два його потенційні значення: 1) вихід англійської мови $з$ активного використання в Європейському Союзі; 2) розпад Сполученого Королівства, вихід Англії з СС та ініціативу Шотландії, Північної Ірландії та Уельсу повернутися в склад Євроспільноти. Наприклад, стаття в The Economic Times проводить паралелі між постколоніальною Індією, що не відмовилася від англійської мови, і майбутнім Європейським Союзом, якому теж можна не відмовлятися від англійської як lingua franca: "In fact, the continuing expansion of Hinglish, Benglish, Tamlish, Punjlish et al, should serve as an example for the European Union, given that Brexit is on the early-2020 agenda and some believe it means Engxit too. English is like the proverbial potato in Indian cooking - it absorbs the distinct flavours of dishes and enhances its own appeal. Eventually, those dishes without potatoes are unthinkable. The EU must banish any thoughts of allowing (or forcing) English to exit along with Britain or risk alienating countless Europeans who have developed a taste for English" [3].

У зовсім іншому значенні термін ENGXIT використано в статті видання The Atlantic: "The issue in that election becomes radically stark: Brexit or union? The English nationalism that powers Brexit is repelling the rest of the United Kingdom. It's not Brexit. It's Engxit - and Engxit not only from the European Union, but Engxit from Britain, too" [4]. Автор описує ймовірність розпаду Великої Британії та виходу з неї Англії після брекзиту. У англомовному медійному дискурсі також зустрічаємо утворені за цим же принципом терміни WEXIT i SCEXIT, що використовуються на позначення ймовірного виходу Уельсу та Шотландії зі складу Об'єднаного Королівства. Наприклад, гілка обговорення на одному з британських форумів так i називається: "Brexit, Engxit, Wexit or Scexit?" [5].

У статті, присвяченій аналізу функціонування англійської мови в Європейському Союзі після остаточного виходу Великої Британії з СС у грудні 2020 року, ми використовуватимемо термін ENGXIT у значенні виходу англійської мови 3 офіційних і робочих мов Свропейського Союзу або скорочення ï використання у сфері інституційної комунікації ЄС. Оскільки курс на європейську інтеграцію записано до Конституції України, а низку реформ вітчизняного освітнього сектору спрямовано на популяризацію вивчення англійської мови, завдання визначити головні тенденції іï використання в Європейському Союзу після BREXIT уважаємо корисним та актуальним для українських науковців, викладачів-філологів, перекладачів і всіх зацікавлених.

Відразу після оголошення результатів британського референдуму щодо виходу країни з СС 3'явилося чимало коментарів європейських політиків стосовно подальшого використання англійської мови. Найбільшого розголосу набула заява Данути Хюбнер, голови Комітету Європейського Парламенту з конституційних справ: “We have a regulation ... where every EU country has the right to notify one official language. The Irish have notified Gaelic, and the Maltese have notified Maltese, so you have only the U.K. notifying English. If we don't have the U.K., we don't have English" [6]. Французький Президент Еммануель Макрон також відомий своїм радикальними заявами щодо англійської мови в СС. Зокрема, проєвропейське видання Euroactiv наводить низку його цитат із березневих виступів 2018 року: "The situation now is quite paradoxical. English has probably never been as present in Brussels at the time when we are talking about Brexit. (...) This domination is not inevitable. It's up to us to set some rules, to be present, and make French the language with whom one has access to a number of opportunities" [7]. Франція, чия мова була головною робочою мовою СС до середини 90-х рр., періодично намагається відновити цей особливий неформальний статусу своєї національної мови. Італійський політик Еудженіо Джіані також наголошував на необхідності посилення ролі італійської мови після виходу Великобританії з СС: "We have not defended ... our language as we should have, both on the European continent and in the world" [6]. Навіть швидкий аналіз таких заяв дає змогу побачити тенденцію: головні політичні гравці Європейського Союзу - Франція, Німеччина, Італія - розглядають процес брекзиту як нагоду переглянути мовну політику Європейського Союзу. Їхні аргументи можна звести до трьох таких тверджень: 
1. Функціонування офіційних мов у Свропейському Союзі регулюється Положенням, прийнятим іще в 1958 році, до вступу Великої Британії в 1973 році. Згідно із цим положенням, кожна нова країна-член при вступі до Союзу обирає й зазначає лише одну офіційну мову, навіть якщо в країні функціонує кілька мов [8]. Сдина країна, що вказала англійську мову як свою офіційну, - це Велика Британія. Отже, при виході останньої іï мова автоматично втрачає статус у СС. Інші країни-члени $\mathrm{CC}$, як-от: Мальта й Ірландія, де англійською спілкується більшість населення, при вступі до Європейського Союзу зазначили інші мови як свої офіційні - мальтійську й ірландську (Gaeilge) відповідно, отже, теж не гарантують збереження iii статусу - "If we don't have the U.K., we don't have English".

2. Після виходу Великобританії з Свропейського Союзу частка англомовного населення ЄС суттєво скорочується: 360 мільйонів людей, для яких англійська $є$ рідною, до менш ніж 10 мільйонів.

3. Надмірна популярність англійською мови шкодить політиці мультилінгвізму та активному використанню інших мов Свропейського Союзу: "We have not defended ... our language as we should have, both on the European continent and in the world"; "This domination (of English in EU) is not inevitable".

Проте оглядач Politico Тім Кінг бачить нові перспективи для англійської мови в ЄС після виходу Великої Британії.

"At present, the English language can be demonized as belonging to the overweening member state that is perfidious Albion. The French government can therefore argue that English must be counter-balanced by support for its main rival as a second language: French - one of the EU's four founding languages, an official language of three member states and a close relation of other Romance languages such as Italian, Spanish and Portuguese. (...) But remove the U.K. from the EU scene and the English language will be seen and accepted for what it is - not so much an expression of British imperialism as the dominant lingua franca, knowledge of which is now a sine qua non for most aspiring bureaucrats and diplomats" [9]. Зазначене автором протистояння англійської та французької мов - English must be counter-balanced by support for its main rival, використання іменника rival свідчать про постійний мовний конфлікт між Францією та Великою Британією. Отже, частина європолітиків, що закликають до ENGXIT, не завжди самі є прихильниками мультилінгвізму, а просто прагнуть повернути популярність власної мови на теренах $Є \mathrm{C}$.

Чимало дослідників уважає, що BREXIT $е$ своєрідною культурною революцією, яка здатна звільнити англійську мову в Європейському
Союзі від контролю Великої Британії. Марко Модіано в праці "English in a post-Brexit European Union" порівнює цей процес із духом «лінгвістики звільнення», теорії, що бере свій початок у науковому доробку індійського лінгвіста Браджа Kачру: "English within the EU now has extensive governmental, educational, informational, and work-related functionality, as well as increasing utility in the creation of intellectual properties. When Britain leaves the EU, the sociolinguistic space for a European variety (or varieties) of English will become even more unambiguous, given the absence of Britain as an arbiter of correctness and standardization" $[10$, с. 314]. Учений уважає, що англійська мова під впливом культури, політики та мовної різноманітності Свропейського Союзу поступово розвинулася в іiі самостійний, унікальний варіант. Саме цей варіант англійської мови, відомий як European English or Euro-English, може значно поширитися на території Європейського Союзу після 2021 року. Щоб краще зрозуміти еволюцію англійської мови та перспективи ії використання після брекзиту, проаналізуймо історію іiі офіційного використання в СС.

Мовна політика Європейського Союзу була та $€$ в центрі великої кількості інтердисциплінарних досліджень як до брекзиту [11; 12], так і після нього $[10 ; 13]$. Сам Європейський Союз у розв'язанні мовних питань керується статтями: 53 Угоди про Європейський Союз, 342 Договору про функціонування Європейського Союзу, 22 Хартії основних прав Свропейського Союзу. Вони проголошують рівність усіх мов СС і наголошують на відсутності будь-яких відмінностей у статусі офіційних і робочих мов. Усі офіційні мови СС є також його робочими мовами, однак на практиці в європейських установах найчастіше використовуються три мови - англійська, французька та німецька [14, с. 216].

Історія Європейського Союзу починається зі створеної в 1951 році Європейської спільноти вугілля та сталі (далі - ЄСВС). Мовою офіційної комунікації в ССВС була французька - мова трьох із шести держав-засновниць, мова європейської дипломатії, мова найбільшої держави-члена ЄСВС. Навіть після вступу Великої Британії до Європейської Спільноти в 1973 році французька мова продовжувала домінувати. Лише в 1996 році використання англійської мови в первинних текстах Свропейської комісії перевищило французьку $[15$, с. 110]. Більшість дослідників погоджується, що є кілька соціополітичних передумов такого поширення англійської мови в СС упродовж останніх десятиліть:

1. Вступ до ЄС у 1995 році північних країн, таких як Фінляндія та Швеція, де англійська мова $€$ надзвичайно поширеною. 
2. Вступ до $\mathrm{CC} \mathrm{у} 2004$ році низки пострадянських держав (Польща, Литва, Латвія, Естонія, Угорщина), де вивчення англійської мови після виходу з комуністичного табору розглядалося як курс на Захід, а відтак було дуже політичним і популярним водночас. До того ж, окрім російської та англійської, доступ до вивчення інших іноземних мов був значно гіршим.

3. Свропейська комісія використовувала виключно англійську мову під час переговорних процедур з державами-кандидатами [16, с. 157].

Аналіз сучасної мовної ситуації Європейського Союзу буде неповним без огляду політики мультилінгвізму. Фактичним стартом багатомовності в СС можна вважати 1958 рік, коли Європейська Рада оголосила мови всіх держав-членів офіційними та робочими мовами європейських установ. Визначити одну офіційну мову Спільноти 3-поміж мов держав-засновниць було політично неправильно й небезпечно. Свропа оговтувалася від двох світових воєн, тож, щоб уникнути будь-якого потенційного конфлікту, обрала курс на лінгвістичний плюралізм. Варто зауважити, що тоді європейська багатомовність грунтувалася на принципах рівного використання лише чотирьох мов: німецької, французької, італійської та голландської, а отже, утілювати ії було значно легше.

Услід за Р. Ріндрел Шйрве й Е. Феттер [17, с. 21] польська дослідниця Е. Кужелевська припускає, що найважливіший етап запровадження політики мультилінгвізму СС пов'язаний із призначенням у 2007 році Леонарда Орбана Уповноваженим 3 питань багатомовності [12]. Сучасна політика мультилінгвізму в Європейському Союзі грунтується на рівності всіх 24 офіційних мов ЄС. Одним із головних завдань мультилінгвізму $\epsilon$ забезпечення рівних прав громадян $\mathrm{CC}$ : права на доступ до офіційних документів своєю національною мовою та права на доступ до європейських установ без мовних бар'єрів. Попри десятки ініціатив популяризувати вивчення іноземних мов, серед яких - Barcelona Objective [18], більшість громадян $Є \mathrm{C}$ мовою міжкультурної комунікації вважає англійську, вона домінує в освіті, науці, торгівлі, туризмі та культурі.

У 2012 році Генеральний директорат Європейської комісії з комунікацій опублікував результати «Спеціального Євробарометра 386 Європейці та їхні мови» - опитування, покликаного визначити ставлення громадян $\mathrm{CC}$ до іноземних мов і багатомовності в Європейському Союзі. У п'ятірку найбільш поширених іноземних мов, якими володіють громадяни $\mathrm{CC}$, входять англійська мова (з великим відривом - 38\%), друге і третє місце посідають французька (12\%) і німецька (11\%) мови відповідно, іспанська (7\%) посідає четверте та російська (5\%) - п'яте [19]. Англійська мова також $є$ головною мовою комунікації між працівниками інституцій $\mathrm{CC}$, парламентарями й культурними операторами, чиї рідні мови різняться.

Згідно з результатами міжнародного дослідницького проєкту "European Language Diversity for All" (ELDIA), європейська багатомовність не $\epsilon$ поширеним явищем. Мультилінгвізм у кращому випадку підтримує індивідуальну багатомовність у районах проживання мовних меншин або регіонах, де мовами розмовляють локалізовано, проте поки ця політик не сприяє широкій соціальній багатомовності в умовах мобільності та глобалізації. Інше європейське дослідження - "Languages in a Network of European Excellence" - демонструє, що головним інструментом міжкультурного спілкування в $€ \mathrm{C} \epsilon$ англійська мова, вона також полегшує процес вивчення інших мов СС. У проєкті LINEE англійська мова постає як нейтральна спільна мова з лише маргінальним національним підтекстом [20, с. 90].

Англійська мова $\epsilon$ також головною мовою перекладу в СС. Загалом щороку Європейський Союз витрачає мільйони євро на переклад, але швидкість, із якою публікуються документи англійською мовою, значно випереджає їх аналоги литовською чи польською. За даними перекладацької компаніï Venga Global, лише Європейська комісія потребує перекладу приблизно двох мільйонів сторінок офіційних документів у рік. $€ C$ наймає понад 5000 усних і письмових перекладачів, 22\% яких працюють над перекладами законів, 17\% - над звітами держав-членів. Перекладу також потребують десятки вебсайтів, сотні офіційних і менш формальних заходів. Важливим залишається факт: 80\% внутрішніх документів ЄС написані англійською мовою, а отже, перекладачі, які працюють із ними, однією з робочих мов мають англійську [21]. Навіть після виходу Великобританії з Європейського Союзу буде складно швидко переорієнтувати ввесь перекладацький штат і забезпечити безперебійний доступ до важливих документів іншими офіційними мовами ЄC. Чимало перекладацьких компаній, як, наприклад, уже вищезгадана Venga Global, пропонують послуги з локалізації та перекладу документів відповідно до норм Euro-English, отже, цей варіант англійської мови отримує дедалі ширше розповсюдження у світі. У 2016 році Джеремі Гарднер, старший перекладач Європейської рахункової палати, опублікував своєрідні методичні рекомендації "Misused English Words and Expressions in EU Publications", щоб показати типові відхилення від стандартів британського варіанта англійської мови у сфері інституційної комунікації ЄС. Проте багато хто з його колег-перекладачів і вчених-лінгвістів сприймає цю працю як доказ становлення самостійного варіанта континентальної англійської мови. 
Підходи до розуміння феномена Euro-English у сучасній лінгвістиці та політології можна умовно поділити на три напрями:

1. Сприйняття Euro-English як спрощеної піджин-мови, що виникла через необхідність контакту між представниками різних етнічних і мовних груп та обмежується словником зі 1500 специфічних слів і словосполучень.

2. Сприйняття Euro-English як своєрідного жаргону євроінституцій - Eurospeak.

3. Сприйняття Euro-English як нового варіанта англійської мови, що характеризується власними лексичними та граматичними й особливостями використання. Останнє бачення стає дедалі популярнішим особливо у світлі досліджень М. Модіано, Дж. Дженкінс, Б. Зайдельхофер, Д. Кристала.

На думку М. Модіано, «високий рівень володіння англійською мовою, повторюваність і систематичність відмінностей у іiі континентальному варіанті не дають змоги віднести іiі до мови-піджин» [10, с. 322]. Серед термінів, які використовують для номінації цього варіанта англійської мови, найчастіше зустрічаємо вже зазначений Euro-English або European English, а також Eurish, Brussels English, Continental English та Eurolish. М. Модіано, Дж. Дженкінс, Б. Зайдельхофер іще в статті 2001 року "EuroEnglish" аналізують особливості цього варіанта англійської мови через призму власних мов і культур - шведської, італійської та австрійської відповідно. Указуючи на нові особливості Euro-English (наприклад, появу унікальних політичних або культурних явищ і слів на їх позначення (Member-States, Schengen)); граматичних конструкцій, типових для інших європейських мов (we were 5 people at the party замість there were 5 people at the party), вони доходять висновку, що чимало таких відмінностей уже міцно закріпилися в континентальному варіанті англійської мови.

Висновки й перспективи подальших розробок. Наші спостереження свідчать, що багато європейських мов мають спільні лексичні або граматичні риси, які водночас не характерні для англійської мови. Допущені мовцем, такі помилки не ідентифікуються іншими співрозмовниками, для яких англійська теж не $є$ рідною, як неправильні. Отже, вони швидше потрапляють до щоденного вжитку й поступово стають частиною словника євроанглійської. Наприклад, уживання прикметника actual у значенні current, адже в низці європейських мов є співзвучні слова: aktuell - у німецькій мові, actuel - у французькій мові, attuale - в італійській мові, aktualny - у польській мові, усі вони мають значення актуальний.

Нещодавній вихід Великобританії з Євроспільноти призвів до масштабних суспільних змін. Одним із центральних питань сучасної європейської соціолінгвістики стало майбутнє анг- лійської мови в ЄС. Сценарії, що розглядалися, передбачали й ENGXIT, тобто повний вихід англійської мови з офіційного використання в ключових інституціях $\mathrm{CC}$ i, навпаки, Euro-English, тобто поширення та стандартизацію нового варіанта англійської мови.

Хоча термін ENGXIT привернув нашу увагу на початку дослідження, аналіз частотності його використання та відсутність фіксації значень у словниках свідчать не лише про непопулярність самого слова в сучасному англомовному дискурсі $€ \mathrm{C}$, а й про неготовність Євроспільноти відмовитися від англійської мови як lingua franca. Натомість у публікаціях англомовних медійних видань після 2016 року особливо часто зустрічаються висловлювання щодо європейського варіанта англійської мови (Euro-English), тож припускаємо, що вихід Великобританії з ЄС може слугувати поштовхом до кодифікації нового варіанта англійської мови.

Перспективи подальшого дослідження вбачаємо в аналізі лексичних і граматичних особливостей європейського варіанту англійської мови та його поширення на теренах $\mathrm{CC} \mathrm{та} \mathrm{України.}$

\section{ЛІТЕРАТУРА}

1. Brexit added to Oxford English Dictionary. BBC News. URL: https://www.bbc.com/news/ uk-england-oxfordshire-38326516 (дата звернення: 05.03.2021).

2. Oxford English Dictionary Online. URL: https://www.oxfordlearnersdictionaries.com/ definition/english/brexit?q=brexit (дата звернення: 05.03.2021).

3. Brexit should not mean Engxit too. The Economic Times. URL: https://economictimes.indiatimes. $\mathrm{com} / \mathrm{magazines} /$ panache/brexit-should-notmean-engxit-too/articleshow/73053489.cms (дата звернення: 05.03.2021).

4. Frum D. Johnson Promised Brexit - But May Deliver Engxit. The Atlantic. 2017. URL: https:// www.theatlantic.com/ideas/archive/2019/10/ brexit-redux/600205/ (дата звернення: 05.03.2021).

5. Brexit, Engxit, Wexit or Scexit? Forums - Contractor UK Bulletin Board. URL: https://www.contractoruk.com/forums/ general/117900-brexit-engxit-wexit-or-scexit-8. html (дата звернення: 06.03.2021).

6. Goulard H. English will not be an official EU language after Brexit, says senior MEP. Politico. 2016. URL: https://www.politico.eu/article/ english-will-not-be-an-official-eu-languageafter-brexit-senior-mep/ (дата звернення: 05.03.2021).

7. Macron says too much English spoken in pre-Brexit Brussels. Euroactiv. URL: 
https://www.euractiv.com/section/french-language/ news/macron-says-too-much-english-spoken-inpre-brexit-brussels/ (дата звернення: 05.03.2021).

8. EEC Council. Regulation No 1 determining the languages to be used by the European Economic Community. EUR-Lex. URL: https://eur-lex. europa.eu/eli/reg/1958/1(1)/oj (дата звернення: 06.03.2021).

9. King T. De Gaulle, Brexit and the slow death of two languages. Politico. 2016. URL: https://www.politico.eu/article/charles-degaulle-brexit-slow-death-two-languages-davidcameron-referendum-power/ (дата звернення: 06.03.2021).

10. Modiano M. English in a post-Brexit European Union. World Englishes. 2017. № 36 (1). P. 313-327. URL: 10.1111/weng.12264 (дата звернення: 06.03.2021).

11. Bhatia T., Ritchie W. The Handbook of Bilingualism and Multilingualism. Oxford : Blackwell Publishing Ltd., 2014. 964 p.

12. Mamadouh V. The Geopolitics of Multilingualism in the European Union. Abingdon : Taylor \& Francis, 2020. 244 p.

13. Kużelewska E. Quo Vadis English? The Post-Brexit Position of English as a Working Language of the EU. International Journal for the Semiotics of Law. URL: https://doi. org/10.1007/s11196-020-09782-х (дата звернення: 06.03.2021).

14. Kużelewska E. Wpływ Brexitu na status języka angielskiego w Unii Europejskiej. Srodkowoeuropejskie Studia Polityczne. № 2. P. 213-227. URL: https://doi.org/10.14746/ ssp.2019.2.12 (дата звернення: 06.03.2021).

15. Truchot C. Languages and Supranationality in Europe: The Linguistic Influence of the European Union. Languages in a Globalising World. Cambridge : Cambridge University Press, 2003. P. 99-110.

16. Kużelewska E. Unity in Diversity. The Language Policy of the European Union. Studies in Logic, Grammar and Rhetoric. 2014. № 38 (51). P. $151-165$.

17. Rindler Schjerve R., Vetter E. European Multilingualism: A highly fragmented and challenging field of research. Linguistic Diversity in Europe. Current trends and Discourses. Berlin : De Gruyter Mouton, 2012. P. 21-47.

18. Council of the European Union. Council conclusions on language competences to enhance mobility. URL: https://www.consilium. europa.eu/uedocs/cms_data/docs/pressdata/en/ educ/126373.pdf (дата звернення: 07.03.2021).

19. European Commission. Special Eurobarometer 386: Europeans and their Languages. EU Open Data Portal. URL: https://data.europa.eu/euodp/
en/data/dataset/S1049 771 EBS386

(дата звернення: 07.03.202ㅍ).

20. Biskub I., Danylchuk A. European Identity: Values, Cultures, and Languages. Language. Culture. Politics : international journal. 2019. № 1. P. 81-92.

21. Brunder E. English without the English: What the Brexit Means for Translation. URL: https://www. vengaglobal.com/blog/english-without-englishbrexit-means-translation/ (дата звернення: 06.03.2021).

\section{REFERENCES}

1. BBC. (2016, December 15). Brexit added to Oxford English Dictionary. BBC News. Retrieved March 5, 2021, from https://www.bbc.com/news/ uk-england-oxfordshire-38326516.

2. Oxford English Dictionary. (2020, December). Oxford English Dictionary. OED Online. Retrieved March 5, 2021, from https://www.oxfordlearnersdictionaries.com/ definition/english/brexit?q=brexit.

3. ET Bureau. (2020, January 1). Brexit should not mean Engxit too. The Economic Times. Retrieved March 5, 2021, from https://economictimes.indiatimes.com/magazines/panache/brexit-shouldnot-mean-engxit-too/articleshow/73053489.cms.

4. Frum, D. (2019, October 17). Johnson Promised Brexit-But May Deliver Engxit. The Atlantic. Retrieved March 5, 2021, from https://www.theatlantic.com/ideas / archive/2019/10/brexit-redux/600205/.

5. Contractor UK. (2016, November 21). Brexit, Engxit, Wexit or Scexit? Forums - Contractor UK Bulletin Board. Retrieved March 6, 2021, from https://www.contractoruk.com/forums/general/117900-brexit-engxit-wexit-or-scexit-8.html.

6. Goulard, H. (2016, June 27). English will not be an official EU language after Brexit, says senior MEP. Politico. Retrieved March 5, 2020, from https:/www.politico.eu/article/englishwill-not-be-an-official-eu-language-after-brexitsenior-mep/.

7. Euroactiv with AFP and Reuters. (2018, March 21). Macron says too much English spoken in pre-Brexit Brussels. Euroactiv. Retrieved March 5, 2021, from https:/www.euractiv.com/ section/french-language/news/macron-says-toomuch-english-spoken-in-pre-brexit-brussels/.

8. EEC Council. (1958, October 6). Regulation No 1 determining the languages to be used by the European Economic Community. EUR-Lex. Retrieved March 6, 2021, from https://eur-lex. europa.eu/eli/reg/1958/1(1)/oj.

9. King, T. (2016, April 28). De Gaulle, Brexit and the slow death of two languages. Politico. Retrieved March 6, 2021, from 
https://www.politico.eu/article/charles-degaulle-brexit-slow-death-two-languages-davidcameron-referendum-power/.

10. Modiano, M. (2017, September). English in a post-Brexit European Union. World Englishes, 36(1), 313-327. 10.1111/weng.12264.

11. Bhatia, T., \& Ritchie, W. (2014). The Handbook of Bilingualism and Multilingualism. Oxford: Blackwell Publishing Ltd.

12. Mamadouh, V. (2020). The Geopolitics of Multilingualism in the European Union. Abingdon: Taylor \& Francis.

13. Kużelewska, E. (2020, October 19). Quo Vadis English? The Post-Brexit Position of English as a Working Language of the EU. International Journal for the Semiotics of Law. https://doi.org/10.1007/s11196-020-09782-x.

14. Kużelewska, E. (2019, June 28). Wpływ Brexitu na status języka angielskiego w Unii Europejskiej. Środkowoeuropejskie Studia Polityczne, (2), 213-227. https://doi.org/10.14746/ssp.2019.2.12.

15. Truchot, C. (2003). Languages and Supranationality in Europe: The Linguistic Influence of the European Union. In Languages in a Globalising World (pp. 99-110). Cambridge: Cambridge University Press.

16. Kużelewska, E. (2014). Unity in Diversity. The Language Policy of the European Union.
Studies in Logic, Grammar and Rhetoric, 38(51), 151-165.

17. Rindler Schjerve, R., \& Vetter, E. (2012). European Multilingualism: A highly fragmented and challenging field of research. In Linguistic Diversity in Europe. Current trends and Discourses (pp. 21-47). Berlin: De Gruyter Mouton.

18. Council of the European Union. (2011, November 28). Council conclusions on language competences to enhance mobility. Europa.eu. Retrieved March 7, 2021, from https://www.consilium. europa.eu/uedocs/cms_data/docs/pressdata/en/ educ/126373.pdf.

19. European Commission. (2012, June 21). Special Eurobarometer 386: Europeans and their Languages. EU Open Data Portal. Retrieved March 7, 2021, from https://data.europa.eu/ euodp/en/data/dataset/S1049_77_1_EBS386.

20. Biskub, I., \& Danylchuk, A. (2019). European Identity: Values, Cultures, and Languages. Language. Culture. Politics : international journal, (1), 81-92.

21. Brunder, E. (2019, December). English without the English: What the Brexit Means for Translation. Venga. Retrieved March 7, 2021, from https:// www.vengaglobal.com/blog/english-without-english-brexit-means-translation/. 